\title{
Implementasi Metode Tanya Jawab Dalam Meningkatkan Kemampuan Membedakan Antara Fakta Dan Opini Dalam Teks Iklan
}

\author{
DESNI YULIET \\ Tenaga Pengajar pada Dinas Pendidikan Kabupaten Kampar \\ SMP Negeri 4 Siak Hulu \\ Email: desniyuliet@yahoo.com
}

\begin{abstract}
Ad text can be judged objectively for customers where it is clear that the purpose of advertising is to attract customers to buy the products offered. In the Indonesian language, a learner needs to be able to distinguish between facts and opinions in the advertisement, because during this time the success of learners to distinguish them is still low. Through the type of classroom action research by applying the question and answer method about advertisement and data is analyzed using qualitative method, hence obtained result that implementation of question and answer method can increase learners ability to distinguish between fact and opinion in ad text.
\end{abstract}

Keywords: Implementation of $Q \& A$ methods, opinions and facts

Iklan merupakan media yang efektif untuk menyampaikan informasi kepada konsumen. Di dalam iklan kita dapat menemukan berbagai macam bentuk kalimat, diantaranya adalah kalimat fakta dan opini. Untuk dapat membedakannya, dalam makalah ini kita akan menjelaskan perbedaan kalimat fakta dan opini.

$\begin{array}{llr}\text { Pada } & \text { pelajaran Bahasa Indonesia } \\ \text { dibahas } & \text { mengenai } & \text { kemampuan }\end{array}$ membedakan antara fakta dan opini dalam sebuah iklan. Siswa diharapkan untuk mampu membedakannya, sehingga dengan kemampuan ini siswa dapat mendapatkan informasi yang tepat dalam berbagai hal untuk mengambil keputusan. Khususnya dalam rangka melaksanakan pendidikan di sekolah pembelajaran ini menjadi sebuah sasaran.

Pendidikan adalah hak setiap warga negara, tak lepas pula adalah siswa yang memiliki keinginan kuat untuk belajar. Pendidikan sebagai bentuk upaya meningkatkan kualitas hidup dan dalam kehidupan, dengan pendidikan orang dapat mengetahui sesuatu dalam dapat memahami serta dapat pula menerapkannya di masyarakat. Hal inilah yang menjadikan orang tersebut manusia yang berguna bagi dirinya sendiri dan berguna bagi masyarakat umumnya. Peran guru dalam pendidikan siswa sangat besar, yang mana siswa belajar tanpa guru menjadi masalah tersendiri. Selain itu guru sebagai sarana untuk menstranfer ilmu kepada peserta didik dalam pembelajaran. Begitu besar peranan guru dalam pendidikan menjadi suatu hal yang tidak bisa dilepaskan, guru memberikan perubahan tersendiri kepada bentuk pengetahuan dan pemahaman siswa akan sesuatu.

Pentingnya peranan guru dalam pembelajaran siswa merupakan bentuk kompetensi yang dimiliki guru, guru dapat mentransfer ilmunya sehingga siswa benar-benar mengetahui dan memahami serta dapat melakukan dalam kehidupan sehari-hari. Hal ini dapat dilihat dari mata pelajaran bahasa indonesia, pelajaran bahasa indonesia salah satunya adalah dalam hal memahami iklan antara fakta dan opini pada layanan televise/ siaran radio kompetensi dasar pelajaran ini adalah menyimpulkan memahami iklan antara fakta dan opini beberapa narasumber pada tayangan televise dan siaran radio.

Untuk dapat mengetahui apakah siswa dapat mengetahui dan membedakan antara fakta dan opini dan terkadang 
siswa terkecoh dengan kondisi yang ada, Kasus di SMP N 4 Siak Hulu khususnya di kelas IX, mengenai rendahnya pemahaman siswa dalam memahami iklan antara fakta dan opini. Hal ini menyebabkan siswa tidak mampu untuk menunjukkan bahwa dirinya sudah paham tentang isi iklan.

$$
\text { Berbeda dengan penelitian }
$$

sebelumnya yang menyarankan menggunakan teknik mind mapping, sebagai salah satu teknik pembelajaran inovatif, dalam pembelajaran menyimak, menulis, dan berbicara pada mata pelajaran Bahasa Indonesia khususnya dan pada pelajaran bahasa yang lain pada umumnya. (Agustawan, I. G. N. O., Sutresna, I. B., Si, M., \& Yasa, I. N, 2014)

Menurut Hidayat, W. (2012) berpikir kritis adalah proses kemampuan siswa untuk mengidentifikasi asumsi yang digunakan; merumuskan pokok-pokok permasalahan; menentukan akibat dari suatu ketentuan yang diambil; mendeteksi adanya bias berdasarkan pada sudut pandang yang berbeda; mengungkap konsep, teorema atau definisi yang digunakan; serta mengevaluasi argumen yang relevan dalam menyelesaikan suatu masalah.

Budiman, K. (2005) menjelaskan di dalam sebuah media massa cetak, khususnya suratkabar dan majalah berita, biasa kita temukan juga halaman khusus yang diperuntukkan bagi karangan-karangan yang berupa opini. Karangankarangan ini di dalam tradisi jurnalistik biasa dibedakan menjadi tajuk rencana (editorial), artikel opini atau kolom (column), dan surat pembaca. Tajuk rencana berisi opini pihak pengelola suratkabar yang diwakili oleh seorang redaktur, biasanya yang sudah senior, mengenai suatu peristiwa aktual.

Metode mengajar memiliki peranan yang sangat penting dalam proses belajar mengajar. Soetomo (1993: 144) menyebutkan: "metode mengajar sebagai suatu alat untuk mencapai tujuan pengajaran yang ingin dicapai, sehingga semakin baik penggunaan metode mengajar semakin berhasillah pencapaian tujuan. Penggunaan metode mengajar secara tepat dapat menumbuhkan minat siswa untuk dapat mengikuti kegaitan belajar mengajar dengan baik, sehingga kreatifitas anak akan muncul dan berkembang dengan baik pula. Namun sebaliknya, jika penggunaan metode mengajar ini kurang tepat, maka akan menjadi tidak bermakna bahkan dapat mematikan kreatifitas siswa.

Metode tanya jawab merupakan cara menyajikan bahan ajar dalam bentuk pertanyaan-pertanyaan yang memerlukan jawaban. Baik dari guru maupun siswa untuk mencapai tuijuan (Mulyasa, 2005: 115). Pertanyaan-pertanyaan dapat muncul dari guru maupun dari siswa. Sedangkan jawaaban juga dapat yang berasal dari guru maupun dari siswa. Masing-masing saling mengisi, baik memberikan pertanyaan maupun jawaban. Penggunaan metode Tanya jawab secara tepat dapat mendorong aktifitas dan kreatifitas berpikir peserta didik.

Fakta adalah hal atau peristiwa yang benar - benar ada atau terjadi dan bisa dibuktikan kebenarannya. Informasi juga dapat disebut dengan fakta apabila informasi itu merupakan peristiwa yang berupa kenyataan yang benar - benar ada dan terjadi.

Opini merupakan suatu pemikiran, perkiraan, atau tanggapan tentang sesuatu hal. Opini adalah pendapat seseorang tentang suatu yang belum tentu kebenarannya. Informasi disebut opini karena informasi tersebut masih berupa pendapat, pikiran, tanggapan, pandangan, dan pendirian seseorang. Opini merupakan persatuan (sintesis) pendapat - pendapat yang sedikit banyak orang baik setuju maupun tidak setuju.

Slameto (1991: 84) menyebutkan bahwa: "mengajar adalah kegiatan mengorganisasi yang bertujuan untuk membantu dan menggairahkan siswa belajar". Mengajar dapat diartikan sebagai proses menyampaikan pengetahuan dan kecakapan tertentu kepada anak didik. Yang lain menyebutkan bahwa mengajar adalah mengorganisasi lingkungan secara kondusif 
sehingga dapat menciptakan siswa yang melakukan proses belajar secara efektif.

Mengajar merupakan aktifitas yang dilakukan oleh guru dalam melakukan interaksi dengan siswa. Aktivitas guru dilakukan secara bertahap, diawali dengan menyusun perencanaan secara menyeluruh tentang segala sesuatu yang akan dilakukan pada saat terjadi interaksi dengan siswa dan pemanfaatan sumber-sumber yang ada untuk mendukung selama kegiatan yaitu melakukan evaluasi, menganalisis dan melakukan pencatatan-pencatratan terhadap sesuatu yang terjadi pada saat interaksi berlangsung.

Pada saat terjadi interaksi dengan siswa, maka guru memilih dan melakukan dengan cara-cara tertentu agar kegiatan interaksi dengan siswa dapat berjalan dengan kondusif sehingga tujuan yang diharapkan dapat tercapai. Cara-cara yang dilakukan oleh guru dalam melakukan interaksi dengan siswa disebut metode mengajar.

Metode mengajar memiliki peranan yang sangat penting dalam proses belajar mengajar. Soetomo (1993: 144) menyebutkan: "metode mengajar sebagai suatu alat untuk mencapai tujuan pengajaran yang ingin dicapai, sehingga semakin baik penggunaan metode mengajar semakin berhasillah pencapaian tujuan. Penggunaan metode mengajar secara tepat dapat menumbuhkan minat siswa untuk dapat mengikuti kegiatan belajar mengajar dengan baik, sehingga kreatifitas anak akan muncul dan berkembang dengan baik pula. Namun sebaliknya, jika penggunaan metode mengajar ini kurang tepat, maka akan menjadi tidak bermakna bahkan dapat mematikan kreatifitas siswa.

Penelitian metode mengajar sangat tergantung pada sutuasi dan kondisi yang mana saat guru mengajar. Tidak semua metode mengajar selalu tepat digunakan untuk menyampaikan materi pelajaran. Metode mengajar sangat banyak ragamnya, antara lain: metode ceramah, metode Tanya jawab, metode diskusi, metode pemberian tugas, metode bermain peran, metode inkuiri, metode demonstrasi, metode pemecahan masalah. Berbagai metode tersebut memiliki kelebihan dan kekurangannya masing-masing.

Metode Tanya jawab merupakan cara menyajikan bahan ajar dalam bentuk pertanyaan-pertanyaan yang memerlukan jawaban. Baik dari guru maupun siswa untuk mencapai tujuan (Mulyasa, 2005: 115). Pertanyaan-pertanyaan dapat muncul dari guru maupun dari siswa. Sedangkan jawaaban juga dapat yang berasal dari guru maupun dari siswa. Masing-masing saling mengisi, baik memberikan pertanyaan maupun jawaban. Penggunaan metode Tanya jawab secara tepat dapat mendorong aktifitas dan kreatifitas berpikir peserta didik.

Dalam penggunaan metode Tanya jawab, pertanyaan-pertanyaan yang akan diajukan kepada anak didik harus sudah dipersiapkan sedemikian rupa, agar kegiatan belajar mengajar tidak menyimpang dari materi pelajaran yang sedang dibahas. Soetomo (1993: 151) menjelaskan langkagh-langkah yang perlu dipersiapkan oleh guru dalam pemberian pertanyaan adalah:

1. merumuskan tujuan secara jelas

2. mengemukakan alasan tentang penggunaan metode Tanya jawab

3. menetapkan pertanyaan-pertyanyaan yang akan diberikan

4. membuat garis besar jawaban dari setiap pertanyaan

5. memberikan kesempatan kepada siswa untuk bertanya

Metode Tanya jawab akan dapat berhasil dengan baik apabila dilaksanakan pada situasi yang tepat dalam proses belajar mengajar. Soetomo (1993: 151-152) menjelaskan bahwa metode tanya jawab tepat digunakan apabila:

1. guru hendak meletakkan hubungan antara pelajaran yang lalu dengan pelajaran yang baru

2. guru hendak memberikan kesempatan kepada anak didik menanyakan hal-hal yang belum dimengerti. 
3. guru melihat keadaan siswa di kelas semakin kurang tertarik terhadap materi yang disampaikan

4. guru hendak mendorong aktivitas dan partisipasi peserta didik dalam kegiatan belajar mengajar.

5. guru hendak mengetahui sejauhmna peserta didik menguasai materi yang telah disampaikan.

Sebagaimana metode mengajar yang lain, metode Tanya jawab tidak selalu baik untuk diteapkan dalam segala situasi. Untuk itu guru diharapkan benar-benar dapat mengambil keputusan secara tepat kapan metode tanya jawab digunakan dalam kegaitan belajar mengajar. Pelaksanaan metode Tanya jawab tidak terlepas dari kelebihan dan kekurangannya. Soetomo (1993: 153) menjelaskan tentang kelebihan dan kelemahan metode Tanya jawab sebagai berikut:

a. Kelebihan metode Tanya jawab

- suasana belajar lebih aktif

- peserta didik memperoleh kesempatan untuk bertanya tentang materi yang belum dipahami

- guru dapat mengetahui tingkat penguasaan peserta didik secara langsung

- dapat melatih peserta didik untuk mengemukakan pendapat secara lisan.

b. Kelemahan metode Tanya jawab

- pertanyaan yang disampaikan cenderung menghendaki jawaban yang bersifat hafalan

- penggunaan secara terus menerus lebih mudah menyimpang dari materi yang sedang dipelajari

- guru sulit mengetahui secara pasti tentang peserta didik yang tidak mengajukan pertanyaan apakah sudah mengusai atau belum.

Berdasarkan uraian tentang kelebihan dan kekurangan tersebut maka setiap guru menggunakan metode Tanya jawab harus mampu memaksimalkan kelebihan dan meminimalkan kekurangan, sehingga penggunaan metode Tanya jawab dapat berhasil sesuai dengan tujuan yang diharapkan.

\section{METODE}

Metode yang digunakan dalam penelitian ini adalah metode penelitian tindakan kelas. Pendekatan yang digunakan dalam penelitian tindakan ini ialah pendekatan kualitatif. Artinya, penelitian ini dilakukan karena ditemukan permasalahan kurangnya pemahaman siswa dalam memahami iklan antara fakta dan opini yang dilihat dari kurang mampunya siswa dalam menjelaskan isi materi dialog interaktif yang dibacanya dalam mata pelajaran bahasa indonesia. Permasalahan ini ditindaklanjuti dengan cara menerapkan sebuah model mengajar tanya jawab yang dilakukan oleh guru kelas. Kegiatan tersebut diamati kemudian dianalisis dan direfleksi. Yang menjadi subjek penelitian tindakan kelas ini adalah guru bersama dengan siswa di kelas IX SMP N 4 Siak Hulu Kabupaten Kampar yang berjumlah 36 orang.

Teknik pengumpulan data dari penelitian tindakan sekolah ini adalah melalui data kualitatif yang diperoleh dari observasi, pengamatan, maupun wawancara. Analisa data yang digunakan dalam penelitian ini adalah analisa data kualitatif yang bersumber dari data primer maupun empiris. Melalui analisa data ini, dapat diketahui ada tidaknya peningkatan pemahaman siswa dalam memahami iklan antara fakta dan opini pada mata pelajaran bahasa indonesia melalui penerapan metode mengajar tanya jawab yang merupakan fokus dari penelitian tindakan kelas ini.

\section{HASIL}

Penelitian tindakan kelas (PTK) ini dilaksanakan dalam tiga siklus. Hal ini dikarenakan keterbatasan waktu yang tersedia, serta dengan tiga siklus sudah penulis anggap cukup untuk peningkatan pemahaman siswa dalam memahami iklan antara fakta dan opini pada sub pelajaran membaca mata pelajaran bahasa indonesia di kelas. 
Melalui tiga siklus dan setiap siklusnya menerapkan tahapan sebagai berikut: terdiri beberapa tahapan, yaitu: 1) Perencanaan; 2) Pelaksanaan; 3) Pengamatan dan 4) Refleksi.

1. Perencanaan. Perencanaan adalah langkah awal yang dilakukan oleh penulis saat akan memulai tindakan. Agar perencanaan mudah dipahami dan dilaksanakan oleh penulis yang akan melakukan tindakan, maka penulis akan membuat rencana tindakan sebagai berikut:

a. Merumuskan masalah yang akan dicari solusinya. Dalam penelitian ini masalah yang akan dicari solusinya adalah: kurangnya pemahaman siswa dalam memahami iklan antara fakta dan opini pada mata pelajaran bahasa indonesia di kelas.

b. Merumuskan tujuan penyelesaian masalah/tujuan menghadapi tantangan/tujuan melakukan inovasi/tindakan. Dalam penelitian ini penulis mengambil rencana untuk melakukan tindakan penerapan metode pengajaran tanya jawab.

c. Merumuskan indikator keberhasilan penerapan metode tanya jawab dalam pemahaman siswa memahami iklan antara fakta dan opini pada mata pelajaran bahasa indonesia pada kelas IX di SMP N 4 Siak Hulu.

d. Merumuskan langkah-langkah kegiatan penyelesaian masalah/kegiatan menghadapi tantangan/kegiatan melakukan tindakan. Langkah-langkah yang diambil penulis dalam melakukan tindakan antara lain adalah melakukan sosialisasi kepada para siswa mengenai penelitian yang akan dilakukan, serta menyampaikan tujuan dari penerapan tindakan yang dilakukan oleh penulis. Kepada para siswa disampaikan mengenai penerapan metode mengajar tanya jawab yang akan diterapkan pada penelitian ini.

e. Mengidentifikasi warga sekolah dan atau pihak terkait lainnya yang terlibat dalam penyelesaian masalah/menghadapi tantangan/melakukan tindakan. Penulis melakukan identifikasi siapa saja yang dilibatkan dalam penelitian ini. Pihakpihak yang dilibatkan dalam penelitian ini adalah: siswa dan guru mata pelajaran bahasa indonesia.

f. Mengidentifikasi metode pengumpulan data yang akan digunakan. Metode pengumpulan data yang diambil oleh penulis merupakan data kualitatif melalui observasi, pengamatan serta wawancara kepada siswa

g. Penyusunan instrumen pengamatan dan evaluasi. Dalam pengambilan data, penulis menggunakan instrumen berupa lembar observasi/pengamatan. Skala penilaian serta angket yang disebarkan kepada siswa, untuk mengetahui penilaian dari siswa mengenai tingkat pemahamannya terhadap memahami iklan antara fakta dan opini dalam bentuk tanya jawab di kelas.

h. Mengidentifikasi fasilitas yang diperlukan. Fasilitas atau alat bantu yang digunakan dalam penelitian ini antara lain: kertas (lembar pengamatan) dan alat tulis berupa balpoint serta kalender dan juga lembar bacaan sertra ruang kelas.

2. Pelaksanaan. Pelaksanaan penelitian tindakan kelas ini dilaksanakan 
melalui beberapa kegiatan, antara lain:

a. Menyebarkan

lembar

pengamatan kepada setiap siswa sebanyak 36 set sesuai dengan banyaknya siswa pada kelas IX di SMP N 4 Siak Hulu 36 orang. Dalam lembar pengamatan itu, telah dibuat pertanyaan mengenai paham atau tidaknya dalam menjawab pertanyaan yang diajukan dan memberikan penjelasan kepada penanya dengan memberikan tanda contreng pada pilihan jawaban yang dianggap paling sesuai.

b. Berkoordinasi dengan guru mata pelajaran bahasa indoensia, guru akan mengajak siswa dalam memahami iklan antara fakta dan opini dan mengadakan tanya jawab.

c. Setelah selesai mengumpulkan data, dilakukan rekapitulasi data penelitian.

d. Kegiatan tersebut dilakukan terus kepada setiap siswa pada tahapannya.

3. Pengamatan. Pengamatan atau observasi dilakukan oleh peneliti, dengan menggunakan lembar observasi selama 1 bulan (satu siklus), untuk semua siswa kelas IX yang berjumlah 36 orang. Selama pengamatan peneliti dibantu atau berkolaborasi dengan guru mata pelajaran bahasa indoensia. Pengamatan oleh peneliti meliputi:

a. merumuskan tujuan secara jelas

b. mengemukakan alasan tentang penggunaan metode Tanya jawab

c. menetapkan pertanyaanpertanyaan yang akan diberikan

d. membuat garis besar jawaban dari setiap pertanyaan

e. memberikan kesempatan kepada siswa untuk bertanya

Rekapitulasi tingkat pemahaman siswa terhadap memahami iklan antara fakta dan opini dilihat dari kemampuan siswa menjawab dan menyampaikan pertanyaan dapat dilihat pada table rekap berikut:

Tabel 1: Rekap seluruh Siklus Kemampuan Membedakan antara Fakta dan Opini

\begin{tabular}{|l|l|c|c|}
\hline Siklus 1 & Rata-Rata & 81 & Tuntas \\
\hline & Tuntas & 26 & $72.2 \%$ \\
\hline & Tidak tuntas & 10 & $27.8 \%$ \\
\hline Siklus 2 & Rata-Rata & 86 & Tuntas \\
\hline & Tuntas & 26 & $72.2 \%$ \\
\hline & Tidak tuntas & 10 & $27.8 \%$ \\
\hline Siklus 3 & Rata-Rata & 91 & Tuntas \\
\hline & Tuntas & 35 & $97.2 \%$ \\
\hline & Tidak tuntas & 1 & $2.8 \%$ \\
\hline
\end{tabular}

\section{PEMBAHASAN}

Dari hasil rekapitulasi data tersebut dapat diketahui pada siklus pertama pemahaman siswa pada memahami iklan antara fakta dan opini dinyatakan kurang, hanya $72,2 \%$, diikuti pada siklus 2 sebesar $72,2 \%$ dan siklus 3 sebesar 97,2\% dari siswa yang tuntas sedangkan sisanya tidak tuntas.

Setelah selesai satu siklus maka diadakan refleksi mengenai kelemahan atau kekurangan dari pelaksanaan tindakan pada siklus pertama. Refleksi dilaksanakan bersama-sama berkolaborator untuk menentukan tindakan perbaikan pada siklus berikutnya. Dari hasil refleksi dapat diambil suatu kesimpulan bahwa perlu penerapan metode tanya jawab kepada siswa dalam memahami iklan antara fakta dan opini perlu mendapatkan penguatan pada siklus berikutnya.

\section{SIMPULAN}

Berdasarkan analisis data, dari penelitian ini dapat ditarik kesimpulan bahwa, penerapan metode mengajar tanya jawab dalam rangka meningkatkan pemahaman siswa memahami iklan antara fakta dan opini di kelas pada mata pelajaran bahasa indonesia ternyata mampu meningkatkan pemahaman siswa. 


\section{DAFTAR RUJUKAN}

Agustawan, I. G. N. O., Sutresna, I. B., Si, M., \& Yasa, I. N. (2014). Penggunaan Teknik Mind Mapping untuk Meningkatkan Kemampuan Siswa dalam Menentukan Fakta dan Opini pada Tajuk Rencana Bali Post di Kelas XI IPA 2 SMA Negeri 1 Sawan. Jurnal Jurusan Pendidikan Bahasa dan Sastra Indonesia, 2(1).

Hidayat, W. (2012). Meningkatkan Kemampuan Berpikir Kritis dan Kreatif Matematik Siswa SMA Melalui Pembelajaran Kooperatif Think-Talk-Write (TTW). In Seminar Nasional Penelitian, Pendidikan dan Penerapan MIPA.

Budiman, K. (2005). Dasar-Dasar Jurnalistik. Makalah yang disampaikan dalam Pelatihan, http://www. w3. org/1999/xhtml">< HEAD $><$ TITLE $>$ Dasar-dasar Jurnalistik. dikutip, 6.

Depdiknas, 2003, Undang-Undang No. 20 Tahun 2003 Tentang Sistem Pendidikan Nasional, Depdiknas.

Slameto, 2003, Belajar dan factor-faktor yang mempengaruhinya, Jakarta: Rineka Cipta.

Slameto, 1991, Proses belajar mengajar dalam sistem kredit semester (SKS) Jakarta: Bumi Aksara

Mulyasa E, 2005, Menjadi guru professional, menciptakan pembelajaran kreatif dan menyenangkan, Bandung. PT. Remaja Rosdakarya Offset.

Soetomo, 1993, Dasar-dasar interaksi belajar mengajar, Usaha nasional, Surabaya 